\title{
DEVELOPMENT OF RAT EMBRYOS CULTURED IN BLOOD SERA
}

\author{
D. A. T. NEW \\ Strangeways Research Laboratory, Cambridge
}

(Received 28th March 1966)

\begin{abstract}
Summary. The growth and differentiation of post-implantation rat embryos together with their embryonic membranes, when grown in vitro in different blood sera, has been assessed by examination of the final stage of development attained and by the weight of protein synthesized. Rat embryos of early somite stages develop well to early limb bud stages when grown in homologous serum. This medium has some advantages over plasma clots. Maximum growth of the embryos is obtained in 0.5 to $1.0 \mathrm{ml}$ serum/embryo. No advantage is gained by adding more serum, or transferring the embryos to fresh serum after a period in culture. It is immaterial whether the serum is obtained from male rats, pregnant or non-pregnant females, from the same individual as the embryos or some other, or from the same variety of rats as the embryos or some other.

Heterologous sera are unsatisfactory as culture media. Rabbit serum is rapidly lethal to rat embryos, but will support some development if pre-heated at 56 to $57^{\circ} \mathrm{C}$ for $30 \mathrm{~min}$. Some samples of fowl serum are rapidly lethal to the rat embryos unless pre-heated, but others support some development.
\end{abstract}

\section{INTRODUCTION}

It has been found previously (New \& Stein, 1964) that rat and mouse embryos of early somite stages will develop to early limb bud stages in drops of embryo extract on the surface of plasma-embryo extract clots. Although this method gives good embryonic development, important disadvantages are that the complex medium is troublesome to prepare, difficult to standardize, and inconvenient for chemical analysis. Another disadvantage is that the embryos are often prevented, probably mechanically, from turning from dorsal to ventral curvature, a change that should occur between the 12- and 18-somite stages.

Studies have been made therefore on the development of rat embryos in allliquid media. Preliminary trials with several chemically defined media were not encouraging, but good results were obtained with homologous serum. In view of the potential value of in-vitro culture methods for mammalian experimental embryology, it seemed worth making a fairly thorough study of development in various blood sera to determine which gave the best results, and whether these results were as good as or better than those obtained from 
development on plasma clots. This paper describes experiments designed to compare development in the following media:

1. Different amounts of rat serum.

2. Serum from pregnant and from non-pregnant female rats.

3. Autologous, homologous and heated rat serum.

4. Serum from male rats and from female rats.

5. Hooded strain embryos in 'Hooded' and in 'Wistar' serum.

6. Rat serum and fowl serum.

7. Rat serum and rabbit serum.

8. Rat serum and sera from calf, horse and sheep.

9. Rat serum and chick plasma clots.

\section{MATERIALS AND METHODS}

Embryos from the 'Hooded' strain of rats were explanted with their embryonic membranes, usually during the 11 th day of gestation, by the method described previously (New \& Stein, 1964). These embryos were at early somite stages. Reichert's membrane was removed and discarded. Plate 1(A) shows the condition of the explant at the beginning of the culture period, and Plate 1(B), (C) and (D) the maximum development attained in culture.

Each explant was placed in a watch glass of diameter $4 \mathrm{~cm}$, in a Petri dish lined with cotton-wool wetted with $0.9 \% \mathrm{NaCl}$ (Text-fig. 1). Except where

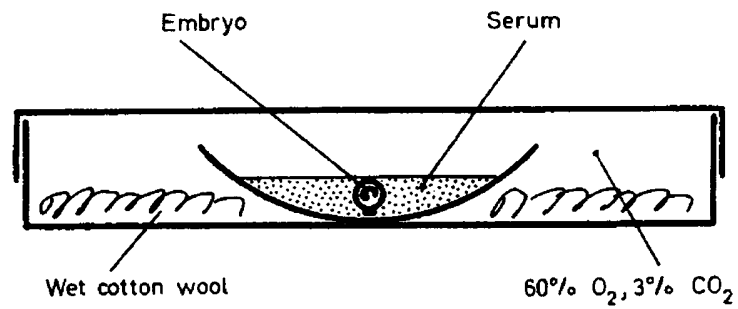

Text-Fig. 1. Petri dish culture chamber. The explant floats in serum in a watch glass surrounded by wet cotton-wool to maintain humidity. The cultures are incubated in 60 to $70 \% \mathrm{O}_{2}$ and 3 to $4 \% \mathrm{CO}_{2}$.

stated otherwise, only one explant was placed in each watch glass. All the cultures were incubated at $37^{\circ} \mathrm{C}$ in 60 to $70 \% \mathrm{O}_{2}$ and 3 to $4 \% \mathrm{CO}_{2}$.

Plasma clots were prepared from 3 parts cock plasma to 1 part chick embryo extract, according to the method of Fell \& Robison (1929).

Rat serum was obtained from blood taken with a siliconed hypodermic syringe and needle from the dorsal aorta of rats anaesthetized with ether. No anticoagulant nor antibiotic was added. The clotted blood was usually allowed to stand overnight in centrifuge tubes, and the serum decanted after centrifugation the following morning. The serum was stored for periods up to 1 week at 1 to $4^{\circ} \mathrm{C}$ or for longer periods at $-10^{\circ} \mathrm{C}$. In making comparisons between different rat sera care was taken that the sera had the same storage treatment.

Fowl serum was prepared in a similar way, from blood obtained from the carotid artery of adult cocks.

Blood for rabbit serum was taken from an ear vein. This procedure is not 


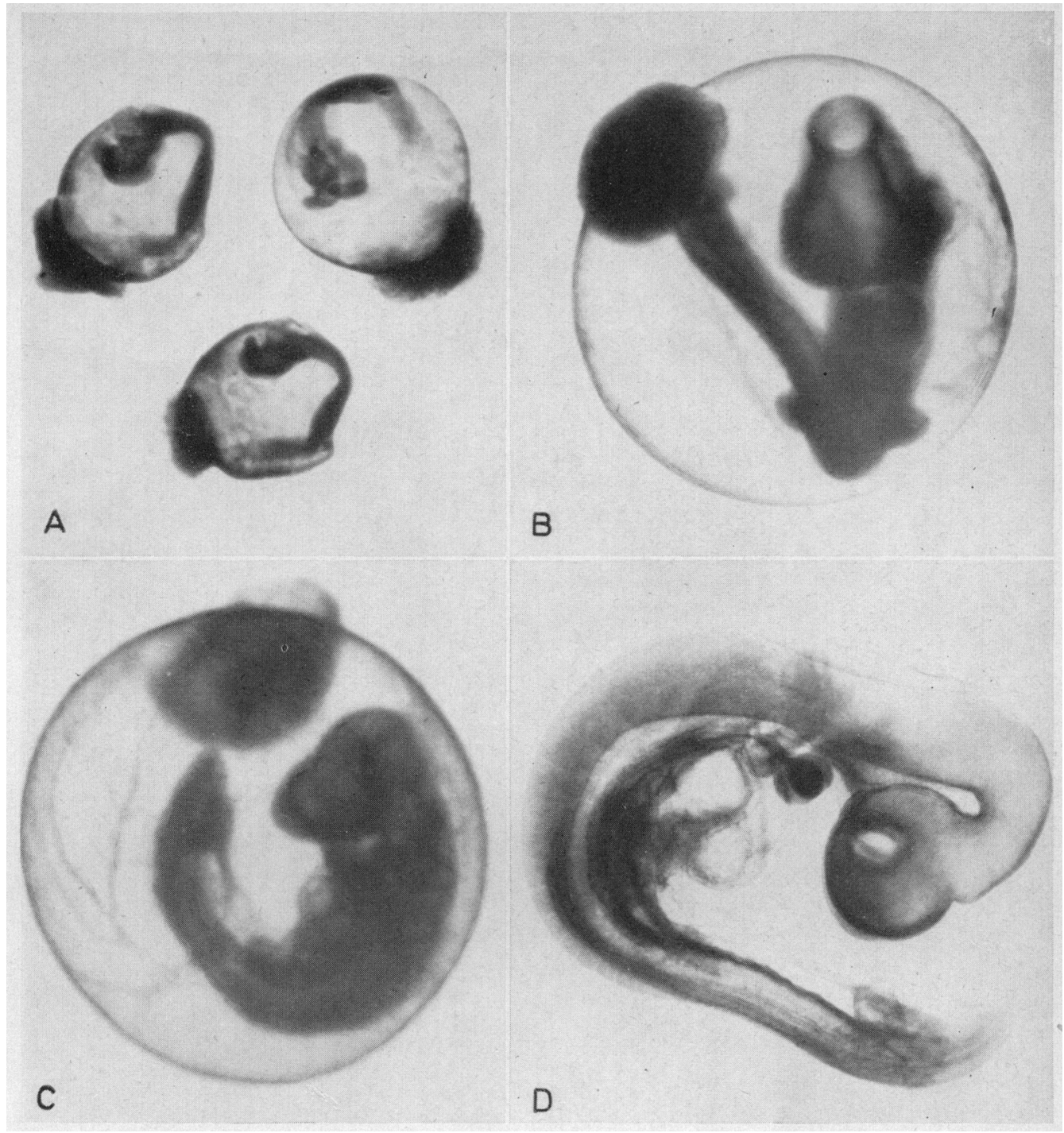

Development of rat embryos in culture.

A. Rat embryos as explanted. Amnion, yolk sac and most of ectoplacental cone left intact, but Reichert's membrane removed. Embryo is curved dorsally $(U) . \times 13$.

$\mathrm{B}$ and $\mathrm{C}$. The explants after development in culture. Embryo now curved ventrally $(C)$ and limb buds developed. Yolk sac much expanded and with network of blood vessels. $\times 13$.

D. Rat embryo grown in culture from 9-somite stage and removed from membranes. Twenty-seven somites and anterior limb buds. $\times 22$.

(Facing p. 510) 
aseptic and the serum was subsequently sterilized by passage through a millipore filter.

The sheep, calf and horse sera were from samples catalogued as 'natural clot, unheated' purchased from Burroughs, Wellcome \& Co., London.

In several of the experiments the serum was pre-heated at 56 to $57^{\circ} \mathrm{C}$ for $30 \mathrm{~min}$, because this treatment is known sometimes to have a beneficial effect (by destruction of complement) on sera used as nutrient media in tissue culture.

\section{Explanation of tables}

To ensure that the embryos used for comparing different media were initially as similar as possible, each litter was divided into groups and one group cultured in each medium.

The amount of embryonic development obtained in each medium was assessed by:

(i) Observations on the embryonic and yolk sac blood circulations, usually after 24 and $44 \mathrm{hr}$ in culture. These are recorded in the tables in four grades, from +++ , indicating a vigorous heart beat and rapid circulation through the entire yolk sac capillary network, to -, indicating no circulation and heart beat slow or absent.

(ii) Final stage of embryo, numbered according to the system of Witschi (1962).

Witschi Stage $15=5$ to 12 somites. Embryo curved dorsally.

Witschi Stage $16=12$ to 20 somites.

Witschi Stage $17=21$ to 25 somites. Embryo curved ventrally. Forelimb buds.

Witschi Stage $18=26$ to 28 somites. Tail bud.

Witschi Stage $19=29$ to 31 somites.

(iii) Curvature of the embryo. $U=$ curved dorsally. $C=$ curved ventrally. Normally the change from $U$ to $C$ is complete in vivo by Witschi Stage 17 .

(iv) Diameter of the yolk sac. The diameter at explantation was 1.5 to $2.5 \mathrm{~mm}$.

(v) Protein content of the explant (embryo+membranes) as determined after digestion in $\mathrm{NaOH}$ and comparison with standard solutions of bovine plasma albumin by the colorimetric method of Lowry, Rosebrough, Farr \& Randall (1951).

\section{RESULTS}

Table 1

Sera from male, pregnant and non-pregnant female rats were used indiscriminately in these cultures, but the same serum was used for all the embryos of any one litter.

A layer of fluid over embryos in culture can sometimes affect development by hindering respiration. But these explants float in rat serum, and are, therefore, as close to the surface in the larger quantities of serum as in the smaller.

The results suggest that less than $0.3 \mathrm{ml}$ serum/embryo (first litter, embryos 1 to 4 , second litter, embryos 1 to 2) is insufficient for maximum development, 


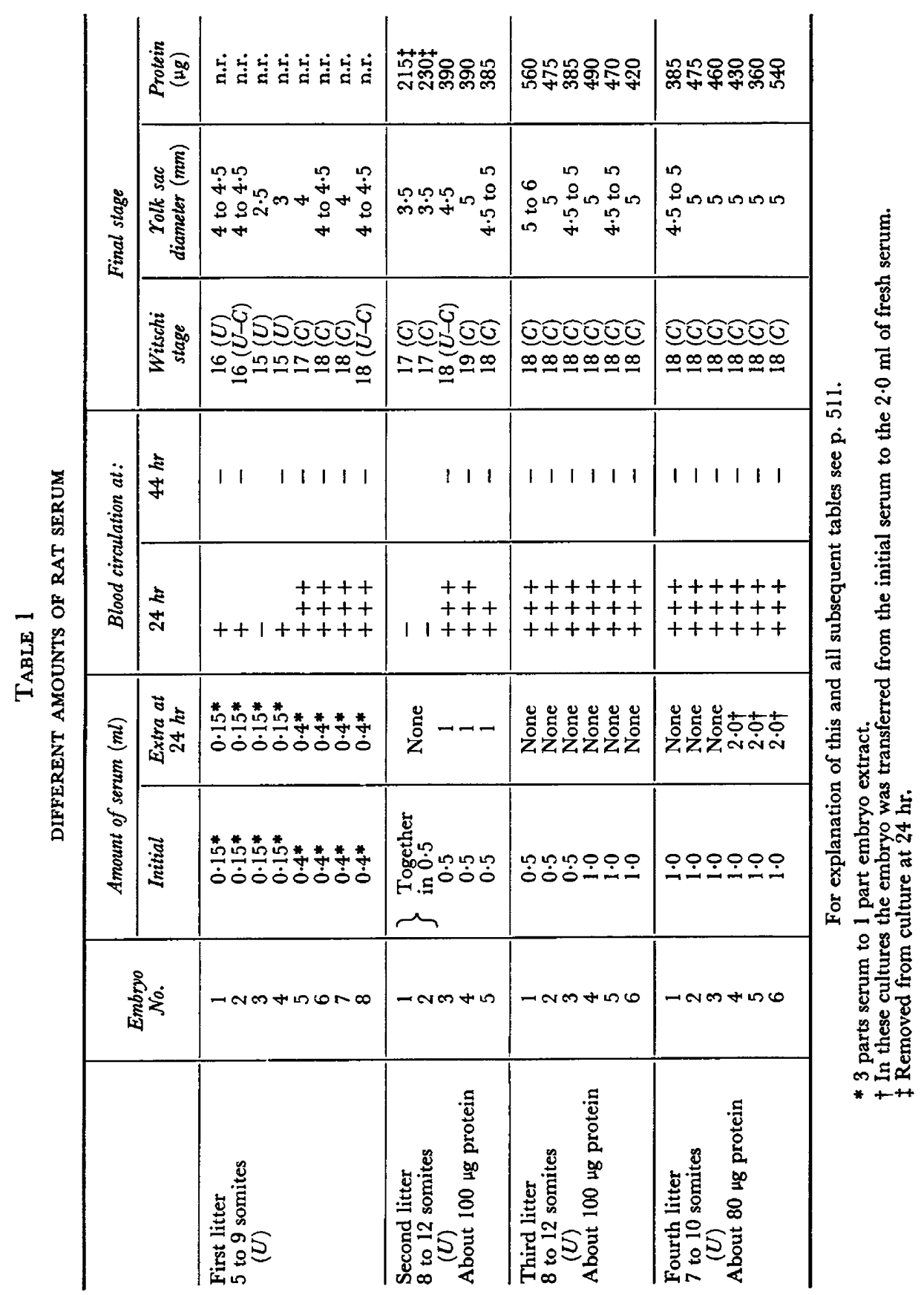


but 0.5 to $1.0 \mathrm{ml}$ is adequate and nothing is gained by adding more, either initially or after $24 \mathrm{hr}$.

\section{Table 2}

The amount of serum for each embryo was initially 0.5 to $0.7 \mathrm{ml}$ with a further 0.7 to $1.0 \mathrm{ml}$ added after $24 \mathrm{hr}$.

It was thought that serum from pregnant rats might contain substances necessary for prolonging development in culture, and if so that such substances would be most likely to be present in serum taken at stages corresponding approximately to that at which embryos in culture usually die (13th day). Three samples of serum from 14-day pregnant rats were tested, and one from an $11 \frac{1}{2}$-day pregnant rat. However, the table shows that none supported better embryonic development than sera from non-pregnant animals.

\section{Table 3}

'Homologous serum' = pooled sera from blood taken from six non-pregnant female rats.

'Autologous serum' = serum taken from the same rat as the embryos.

'Autologous serum (heated)' = serum taken from the same rat as the embryos and heated for $30 \mathrm{~min}$ at 56 to $57^{\circ} \mathrm{C}$.

One litter of $9 \frac{1}{2}$-day embryos was used in this experiment because it had previously been found that embryos of this age do not develop well on clots (New \& Stein, 1964) or in homologous serum, and it was thought possible that they might develop better in autologous serum. However, Table 3(A) shows that no better results are gained by using autologous serum, heated or unheated. The embryos marked ' + ' in the table attained Witschi stages 14 to 15 ( 1 to 12 somites) and had a fairly well formed head and beating heart, but the somites and hind parts were small and poorly developed; the allantois never extended to the ectoplacental cone. The embryos marked ' - ' showed no development in culture. The whole explants (embryo + membranes) enlarged from about $1 \times 0.5 \mathrm{~mm}$ at explantation to the spherical form with yolk sac 2 to $3 \mathrm{~mm}$ diameter at the end of the culture period.

The 101-day embryos (Table 3B) developed well in all three types of serum. There was no indication that they developed better in autologous than in homologous serum. In two ways the development of these embryos was unusual: the persistence of the blood circulation for a longer time than is usual in culture, and the failure of all but one of the embryos to complete the change from dorsal to ventral curvature. Both might be the result of explanting embryos rather younger than usual, or just possibly the failure in turning might be due to some defect caused by the embryos being kept cold for $4 \mathrm{hr}$ while the autologous serum was prepared, instead of the usual time of 1 to $2 \mathrm{hr}$ between killing the rat and transferring the embryo to the incubator.

\section{Table 4}

Each embryo was grown in $1 \mathrm{ml}$ serum taken from the pooled serum from two adult male rats or two adult female rats. 


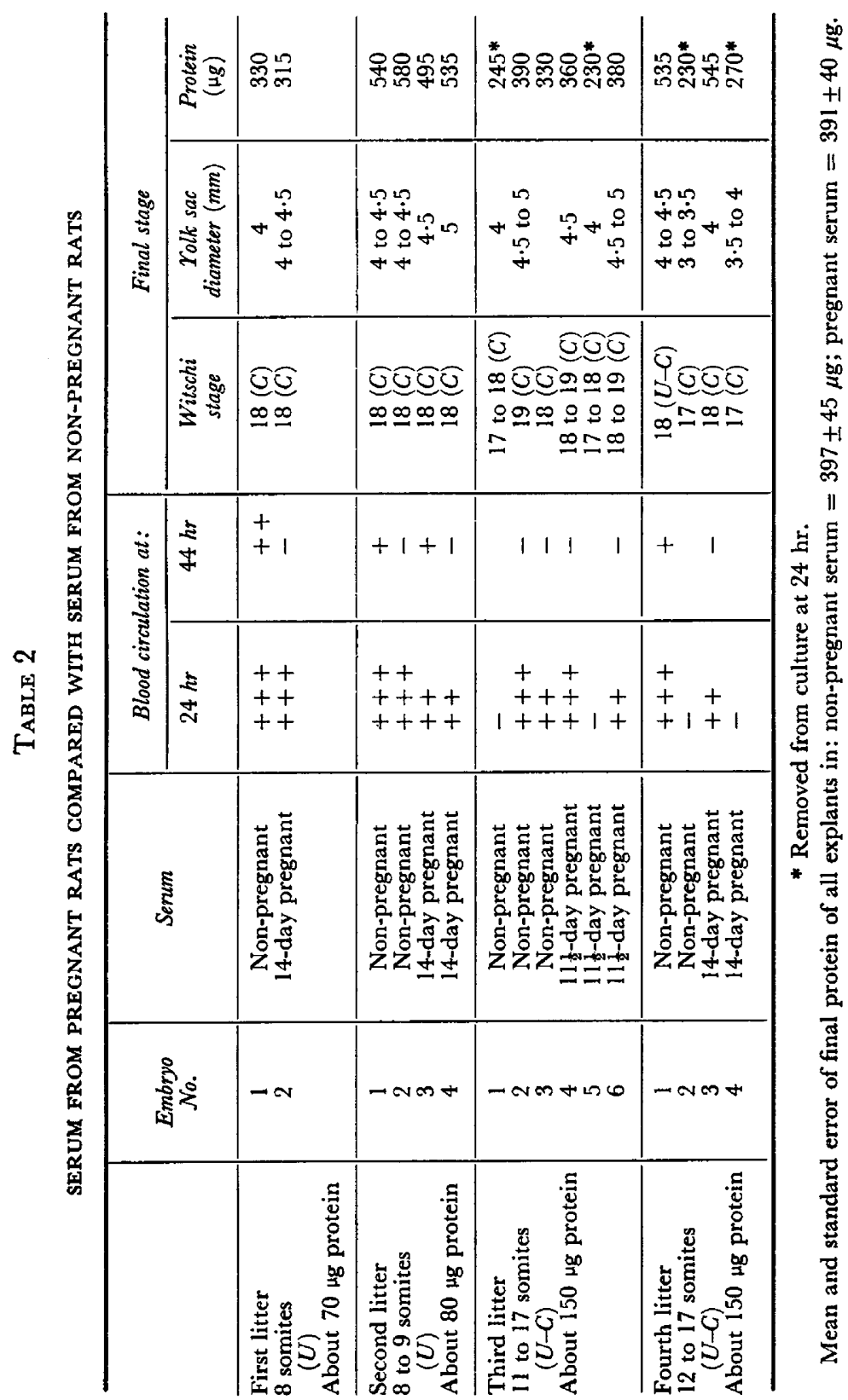


The sera for litters 2 and 4 were from the same rats, those for litter 1 and for litter 3 from different rats. In all, therefore, the sera used in these experiments were from six male rats and six female rats. None of the female rats was pregnant, with the exception of one of those from which serum was obtained for litter 3.

TABLE 3

COMPARISON OF GROWTH IN AUTOLOGOUS, HOMOLOGOUS AND HEATED RAT SERUM

\begin{tabular}{|c|c|c|c|c|c|}
\hline \multirow{2}{*}{$A$} & \multirow{2}{*}{$\begin{array}{c}\text { Embryo } \\
\text { No. }\end{array}$} & \multirow{2}{*}{ Medium } & \multicolumn{3}{|c|}{ Final stage (at $65 \mathrm{hr}$ ) } \\
\hline & & & Embryo & $\begin{array}{c}\text { Yolk sac } \\
\text { diameter }(\mathrm{mm})\end{array}$ & $\begin{array}{l}\text { Protein } \\
(\mu g)\end{array}$ \\
\hline \multirow{3}{*}{$\begin{array}{l}\text { First litter } \\
9 \frac{1}{2} \text {-day } \\
\text { embryos } \\
\text { Primitive } \\
\text { streak to } \\
\text { head-fold }\end{array}$} & $\begin{array}{l}1 \\
2 \\
3\end{array}$ & $\begin{array}{l}\text { Homologous } \\
\text { serum }\end{array}$ & $\begin{array}{l}+ \\
+ \\
-\end{array}$ & $\begin{array}{l}3 \\
3 \\
2\end{array}$ & $\begin{array}{r}200 \\
75\end{array}$ \\
\hline & $\begin{array}{l}4 \\
5 \\
6 \\
7\end{array}$ & $\begin{array}{l}\text { Autologous } \\
\text { serum }\end{array}$ & $\begin{array}{l}+ \\
+ \\
+ \\
+\end{array}$ & $\begin{array}{l}3 \\
3 \\
3 \\
3\end{array}$ & $\begin{array}{l}185 \\
200 \\
185\end{array}$ \\
\hline & $\begin{array}{r}8 \\
9 \\
10 \\
11\end{array}$ & $\begin{array}{l}\text { Autologous } \\
\text { serum, } \\
\text { heated }\end{array}$ & $\frac{\bar{t}}{+}$ & $\begin{array}{l}2 \\
3 \\
2 \\
3\end{array}$ & $\begin{array}{r}95 \\
245 \\
135\end{array}$ \\
\hline
\end{tabular}

\begin{tabular}{|c|c|c|c|c|c|c|c|}
\hline \multirow{2}{*}{$B$} & \multirow{2}{*}{$\begin{array}{c}\text { Embryo } \\
\text { No. }\end{array}$} & \multirow{2}{*}{ Medium } & \multicolumn{2}{|c|}{ Blood circulation at: } & \multicolumn{3}{|c|}{ Final stage $($ at $50 \mathrm{hr}$ ) } \\
\hline & & & $24 h r$ & $40 \mathrm{hr}$ & $\begin{array}{c}\text { Witschi } \\
\text { stage }\end{array}$ & $\begin{array}{c}\text { Yolk sac } \\
\text { diameter }(\mathrm{mm})\end{array}$ & $\begin{array}{c}\text { Protein } \\
(\mu g)\end{array}$ \\
\hline \multirow{3}{*}{$\begin{array}{l}\text { Second litter } \\
10 \frac{1}{2} \text {-day } \\
\text { embryos } \\
3 \text { to } 7 \text { somites } \\
(U) \\
\text { About } 30 \mu \mathrm{g} \\
\text { protein }\end{array}$} & $\begin{array}{l}1 \\
2 \\
3\end{array}$ & $\begin{array}{l}\text { Homologous } \\
\text { serum }\end{array}$ & $\begin{array}{l}+++ \\
+t \\
+++\end{array}$ & $\begin{array}{l}+++ \\
+++ \\
+\end{array}$ & $\begin{array}{c}18(U-C) \\
18(C) \\
18(U-C)\end{array}$ & $\begin{array}{c}5 \\
4 \cdot 5 \text { to } 5 \\
4.5\end{array}$ & $\begin{array}{r}>600 \\
585 \\
585\end{array}$ \\
\hline & $\begin{array}{l}4 \\
5 \\
6\end{array}$ & $\begin{array}{l}\text { Autologous } \\
\text { serum }\end{array}$ & $\begin{array}{l}+++ \\
+\end{array}$ & $\begin{array}{l}+++ \\
++ \\
++\end{array}$ & $\begin{array}{c}18(U-C) \\
16 \text { to } 17(U) \\
16 \text { to } 17(U)\end{array}$ & $\begin{array}{c}4 \cdot 5 \text { to } 5 \\
3 \cdot 5 \\
4\end{array}$ & $\begin{array}{l}595 \\
360 \\
455\end{array}$ \\
\hline & $\begin{array}{l}7 \\
8\end{array}$ & $\begin{array}{l}\text { Autologous } \\
\text { serum, } \\
\text { heated }\end{array}$ & $\overline{+}++$ & $\stackrel{+}{+}$ & $\begin{array}{c}16 \text { to } 17(U) \\
18(U-C)\end{array}$ & $\begin{array}{c}3 \cdot 5 \\
5\end{array}$ & $\begin{array}{l}320 \\
465\end{array}$ \\
\hline
\end{tabular}

The results show that the explants develop equally well in male or female serum. The difference in mean final protein between the two groups of embryos is not significant $(P$ is between 0.5 and 0.6$)$.

\section{Table 5}

Each embryo was grown in $1 \mathrm{ml}$ serum taken from the pooled serum from two or three adult rats. The rats used to supply sera for the second litter were different from those used for the first. 
The results suggest that it is immaterial whether the serum is obtained from the same variety of rat as the embryos or from a different variety.

\section{Table 6}

The explants float in rat serum, but sink in fowl serum, so that if the medium is more than $2 \mathrm{~mm}$ deep there may be a layer of fluid over the explants in the fowl serum thick enough to hinder respiration. The embryos of the first litter

\section{TABLE 4}

SERUM FROM MALE RATS COMPARED WITH SERUM FROM FEMALE RATS

\begin{tabular}{|c|c|c|c|c|c|c|c|}
\hline & \multirow{2}{*}{$\begin{array}{c}\text { Embryo } \\
\text { No. }\end{array}$} & \multirow{2}{*}{ Serum } & \multicolumn{2}{|c|}{ Blood circulation at: } & \multicolumn{3}{|c|}{ Final stage } \\
\hline & & & $24 h r$ & $44 h r$ & $\begin{array}{l}\text { Witschi } \\
\text { stage }\end{array}$ & $\begin{array}{c}\text { Yolk sac } \\
\text { diameter }(\mathrm{mm})\end{array}$ & $\begin{array}{c}\text { Protein } \\
(\mu g)\end{array}$ \\
\hline $\begin{array}{l}\text { First litter } \\
4 \text { to } 7 \text { somites } \\
(U) \\
\text { About } 40 \mathrm{~kg} \\
\text { protein }\end{array}$ & $\begin{array}{l}1 \\
2 \\
3 \\
4 \\
5 \\
6 \\
7 \\
8\end{array}$ & $\begin{array}{c}\text { Male } \\
\text { Male } \\
\text { Male } \\
\text { Male } \\
\text { Female } \\
\text { Female } \\
\text { Female } \\
\text { Female }\end{array}$ & $\begin{array}{l}+++ \\
+++ \\
+++ \\
+++ \\
+++ \\
++ \\
+++ \\
+++\end{array}$ & $\begin{array}{l}+ \\
- \\
- \\
+ \\
\pm \\
-\end{array}$ & $\begin{array}{c}18 \text { to } 19(C) \\
18 \text { to } 19(C) \\
18 \text { to } 19(G) \\
18 \text { to } 19(U-C) \\
18 \text { to } 19(C) \\
17 \text { to } 18(U-C) \\
18 \text { to } 19(C) \\
18 \text { to } 19(U-C)\end{array}$ & $\begin{array}{l}4.5 \text { to } 5 \\
4.5 \text { to } 5 \\
4.5 \text { to } 5 \\
4 \text { to } 4.5 \\
4 \text { to } 4.5 \\
4 \text { to } 4.5 \\
4.5 \text { to } 5 \\
4 \text { to } 4.5\end{array}$ & $\begin{array}{l}365 \\
370 \\
420 \\
305 \\
345 \\
305 \\
410 \\
260\end{array}$ \\
\hline $\begin{array}{l}\text { Second litter } \\
7 \text { to } 9 \text { somites } \\
(U) \\
\text { About } 70 \mu \mathrm{gg} \\
\text { protein }\end{array}$ & $\begin{array}{l}1 \\
2 \\
3 \\
4 \\
5 \\
6\end{array}$ & $\begin{array}{c}\text { Male } \\
\text { Male } \\
\text { Male } \\
\text { Female } \\
\text { Female } \\
\text { Female }\end{array}$ & $\begin{array}{l}+++ \\
+++ \\
+++ \\
+++ \\
+++ \\
+++\end{array}$ & $\begin{array}{l}- \\
\overline{-} \\
- \\
-\end{array}$ & $\begin{array}{l}18 \text { to } 19(C) \\
18 \text { to } 19(C) \\
18 \text { to } 19(C) \\
18 \text { to } 19(C) \\
18 \text { to } 19(C) \\
18 \text { to } 19(C)\end{array}$ & $\begin{array}{c}5 \\
5 \\
5 \text { to } 5 \cdot 5 \\
5 \\
5 \\
5\end{array}$ & $\begin{array}{l}465 \\
525 \\
525 \\
385 \\
460 \\
400\end{array}$ \\
\hline $\begin{array}{l}\text { Third litter } \\
9 \text { to } 16 \text { somites } \\
(U-C) \\
\text { About } 120 \mu \mathrm{g} \\
\text { protein }\end{array}$ & $\begin{array}{l}1 \\
2 \\
3 \\
4 \\
5 \\
6\end{array}$ & $\begin{array}{c}\text { Male } \\
\text { Male } \\
\text { Male } \\
\text { Female } \\
\text { Female } \\
\text { Female }\end{array}$ & $\begin{array}{l}\frac{t+}{t+} \\
+t \\
++t \\
+t\end{array}$ & $\begin{array}{l}- \\
\overline{+} \\
- \\
-\end{array}$ & $\begin{array}{c}19(C) \\
17(U-C) \\
17 \text { to } 18(U-C) \\
16(U-C) \\
19(C) \\
19(C)\end{array}$ & & $\begin{array}{l}395 \\
310 \\
390 \\
220 \\
475 \\
530\end{array}$ \\
\hline $\begin{array}{l}\text { Fourth litter } \\
14 \text { to } 18 \text { somites } \\
(U-C) \\
\text { About } 180 \text { ug } \\
\text { protein }\end{array}$ & $\begin{array}{l}1 \\
2 \\
3 \\
4 \\
5 \\
6\end{array}$ & $\begin{array}{c}\text { Male } \\
\text { Male } \\
\text { Male } \\
\text { Female } \\
\text { Female } \\
\text { Female }\end{array}$ & $\begin{array}{l}++ \\
++ \\
+++ \\
+++ \\
+++ \\
+++\end{array}$ & $\begin{array}{l}- \\
- \\
- \\
- \\
-\end{array}$ & $\begin{array}{l}18 \text { to } 19(C) \\
18 \text { to } 19(C) \\
18 \text { to } 19(C) \\
18 \text { to } 19(C) \\
18 \text { to } 19(C) \\
18 \text { to } 19(C)\end{array}$ & $\begin{array}{c}5.5 \\
5.5 \\
5 \cdot 5 \\
5 \text { to } 6 \\
5 \\
5 \text { to } 5.5\end{array}$ & $\begin{array}{l}605 \\
535 \\
550 \\
605 \\
525 \\
525\end{array}$ \\
\hline
\end{tabular}

Mean and standard error of final protein of all explants in male serum $=443 \pm 26 \mu \mathrm{g}$, in female serum $=419 \pm 31 \mu \mathrm{g}$.

were cultured in $1 \mathrm{ml}$ serum/embryo, which with fowl serum gave initially a layer of fluid 1 to $2 \mathrm{~mm}$ thick above the explants. However, all the embryos from the other litters were grown in $0.5 \mathrm{ml}$ serum/embryo; this was only just sufficient to cover the explants, which were therefore as close to the surface in the fowl serum as in the rat serum.

The fowl serum used for the first and second litters appeared to be rapidly lethal. The embryos placed in it did not develop, the yolk sacs collapsed, and at the end of the culture period all that remained was a lump of disintegrating 
tissue smaller than the original explant. Preheating the serum at 56 to $57^{\circ} \mathrm{C}$ for $30 \mathrm{~min}$ (second litter, embryos 6 and 7) had a very marked effect; the embryos developed fairly normally, though not as well as in rat serum.

The fowl serum used for the third and fourth litters was less harmful, even without pre-heating. The explants placed in it developed, and their yolk sacs expanded. But both in development and protein synthesis they were much inferior to the controls in rat serum.

TABLE 5

COMPARISON OF GROWTH OF 'HOODED' STRAIN EMBRYOS IN 'HOODED' AND IN 'WISTAR' SERUM

\begin{tabular}{|c|c|c|c|c|c|c|c|}
\hline & \multirow{2}{*}{$\begin{array}{c}\text { Embryo } \\
\text { No. }\end{array}$} & \multirow{2}{*}{ Serum } & \multicolumn{2}{|c|}{ Blood circulation at: } & \multicolumn{3}{|c|}{ Final stage } \\
\hline & & & $24 \mathrm{hr}$ & $44 h r$ & $\begin{array}{l}\text { Witschi } \\
\text { stage }\end{array}$ & $\begin{array}{c}\text { rolk sac } \\
\text { diameter }(\mathrm{mm})\end{array}$ & $\begin{array}{c}\text { Protein } \\
(\mu g)\end{array}$ \\
\hline $\begin{array}{l}\text { First litter } \\
7 \text { to } 10 \text { somites } \\
(U) \\
\text { About } 80 \mu \mathrm{g} \\
\text { protein }\end{array}$ & $\begin{array}{l}1 \\
2 \\
3 \\
4 \\
5 \\
6\end{array}$ & $\begin{array}{l}\text { Hooded } \\
\text { Hooded } \\
\text { Hooded } \\
\text { Wistar } \\
\text { Wistar } \\
\text { Wistar }\end{array}$ & $\begin{array}{l}+++ \\
+++ \\
+++ \\
+++ \\
+++ \\
+++\end{array}$ & $\begin{array}{l}- \\
- \\
\overline{-} \\
- \\
-\end{array}$ & $\begin{array}{c}18 \text { to } 19(C) \\
18(U-C) \\
19(C) \\
18 \text { to } 19(C) \\
18 \text { to } 19(C) \\
18 \text { to } 19(C)\end{array}$ & $\begin{array}{c}4 \text { to } 4.5 \\
3.5 \\
4 \\
4 \text { to } 4.5 \\
4 \text { to } 4.5 \\
4 \text { to } 4.5\end{array}$ & $\begin{array}{l}385 \\
315 \\
535 \\
410 \\
375 \\
510\end{array}$ \\
\hline $\begin{array}{l}\text { Second litter } \\
9 \text { to } 13 \text { somites } \\
(U) \\
\text { A bout } 100 \mu \mathrm{g} \\
\text { protein }\end{array}$ & $\begin{array}{l}1 \\
2 \\
3 \\
4 \\
5 \\
6\end{array}$ & $\begin{array}{l}\text { Hooded } \\
\text { Hooded } \\
\text { Hooded } \\
\text { Wistar } \\
\text { Wistar } \\
\text { Wistar }\end{array}$ & $\begin{array}{l}+++ \\
+++ \\
+++ \\
+++ \\
+++ \\
+++\end{array}$ & $\begin{array}{l}? \\
+ \\
+ \\
? \\
+ \\
+\end{array}$ & $\begin{array}{c}17(C) \\
18(U-C) \\
18 \text { to } 19(C) \\
17(C) \\
18(U-C) \\
18(U-C)\end{array}$ & $\begin{array}{c}3.5 \text { to } 4 \\
4.5 \\
4.5 \\
3 \\
4.5 \\
4 \text { to } 4.5\end{array}$ & $\begin{array}{l}340^{*} \\
450 \\
515 \\
350^{*} \\
475 \\
390\end{array}$ \\
\hline
\end{tabular}

* Removed from culture at $24 \mathrm{hr}$.

Mean and standard error of final protein of all explants in 'Hooded' serum $=423 \pm 34 \mu \mathrm{g}$, in 'Wistar' serum $=438 \pm 23 \mu \mathrm{g}$.

Other cultures also have shown that fowl serum is very variable in its effect on rat embryos. The reason is unknown, but length of storage is a possible explanation. The lethal serum used here (first and second litters) had been stored for only 4 to 6 days at 5 to $10^{\circ} \mathrm{C}$ whereas the less harmful serum (third and fourth litters) had been stored for a month. Chang (1949) has shown that heterologous sera which are initially lethal to rabbit eggs gradually become less harmful on storage.

\section{Table 7}

Three samples of rabbit serum were tested, taken from three adult male rabbits on the day before the rat embryos were explanted. All three proved rapidly lethal to the rat embryos. When the cultures were examined after $24 \mathrm{hr}$ all that remained of each explant was a dead, shrunken, and partly disintegrated lump of tissue.

If the rat embryos were immersed in the rabbit serum for only $15 \mathrm{~min}$ and then transferred to rat serum they recovered and developed well (third litter, embryos 2 to 4 ). After $2 \mathrm{hr}$ immersion, however, they were permanently damaged (third litter, embryos 5 to 7 ). 


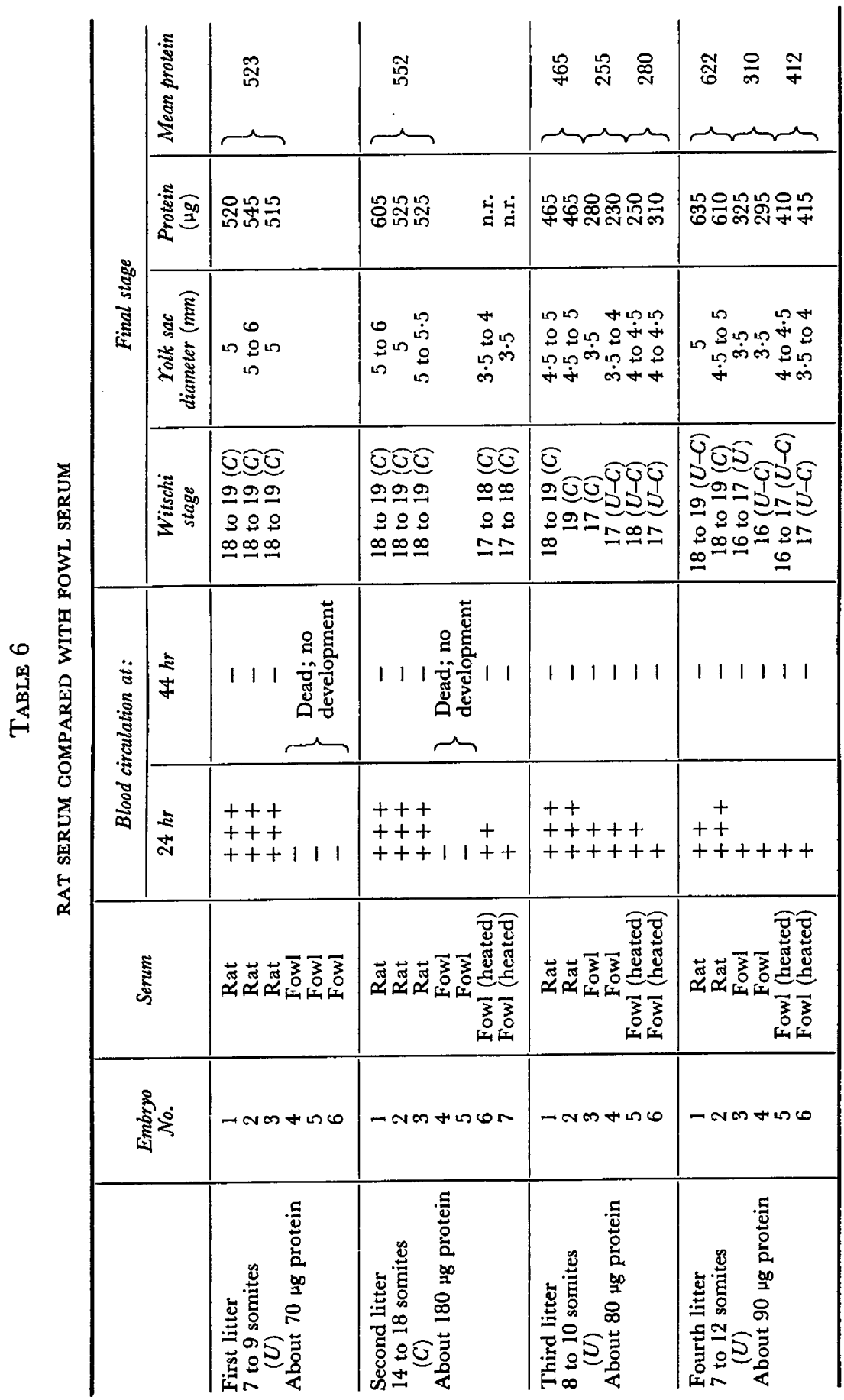


Heating the rabbit serum for $30 \mathrm{~min}$ at 56 to $57^{\circ} \mathrm{C}$ made it less harmful to the rat embryos (first litter, embryos 8 and 9; second litter, embryos 8 and 9), but in the final stage of development attained and the amount of protein synthesized the embryos were still inferior to the controls in rat serum.

\section{Table 8}

The calf, horse and sheep sera were used without prior heat treatment, and after heating to 56 to $57^{\circ} \mathrm{C}$ for $30 \mathrm{~min}$.

Growth of all the explants in the three heterologous sera was very inferior to that of the controls in rat serum. Embryonic development was negligible. There was some protein synthesis, probably mainly in the yolk sac which expanded, but much less than that of the controls. The hearts beat only feebly, no blood circulation was established, and the yolk sac wall was 'bubbly' in appearance-probably owing to abnormal distension of the blood vessels.

The calf serum was a little worse than the horse and sheep sera. No improvement was gained by pre-heating the sera.

\section{Table 9}

The amount of medium varied between the different cultures, and the clot cultures supported up to three embryos per clot. But the volume of medium per embryo was always more than $0.5 \mathrm{ml}$, so that differences of embryonic development are very unlikely to have been caused by differences in quantity of medium (see Table 1).

The amount of protein synthesized by the explants in the all-serum cultures was significantly more than on clots $(P$ is between 0.01 and 0.02$)$. Moreover embryos 3 and 4 of the second litter which were explanted into drops of serum on the clot, and embryos 1 and 2 of the fourth litter which were similarly explanted followed by a later addition of $1.5 \mathrm{ml}$ of serum, synthesized more protein than those embryos from the same litters explanted into embryo extract on clots.

The results from the first and second litters suggest that under certain conditions the blood circulation may persist for longer on clots than in all-serum cultures. This may be a matter of oxygenation; although the explants float in rat serum the yolk sac remains spherical, whereas on clots it is flattened, exposing a larger surface to the gas phase and presumably making possible more rapid respiration.

However, the final stage of development of the embryo, and the growth of the yolk sac, are the same in all-serum cultures as on clots, and in serum fewer embryos fail to make the change from dorsal to ventral curvature. For most purposes, therefore, the all-serum type of culture is much to be preferred.

\section{DISGUSSION}

The work described here shows that for most purposes homologous serum is a better culture medium for rat embryos than chick plasma clots. It is simpler to prepare and gives better growth of the embryos. It appears to make little 


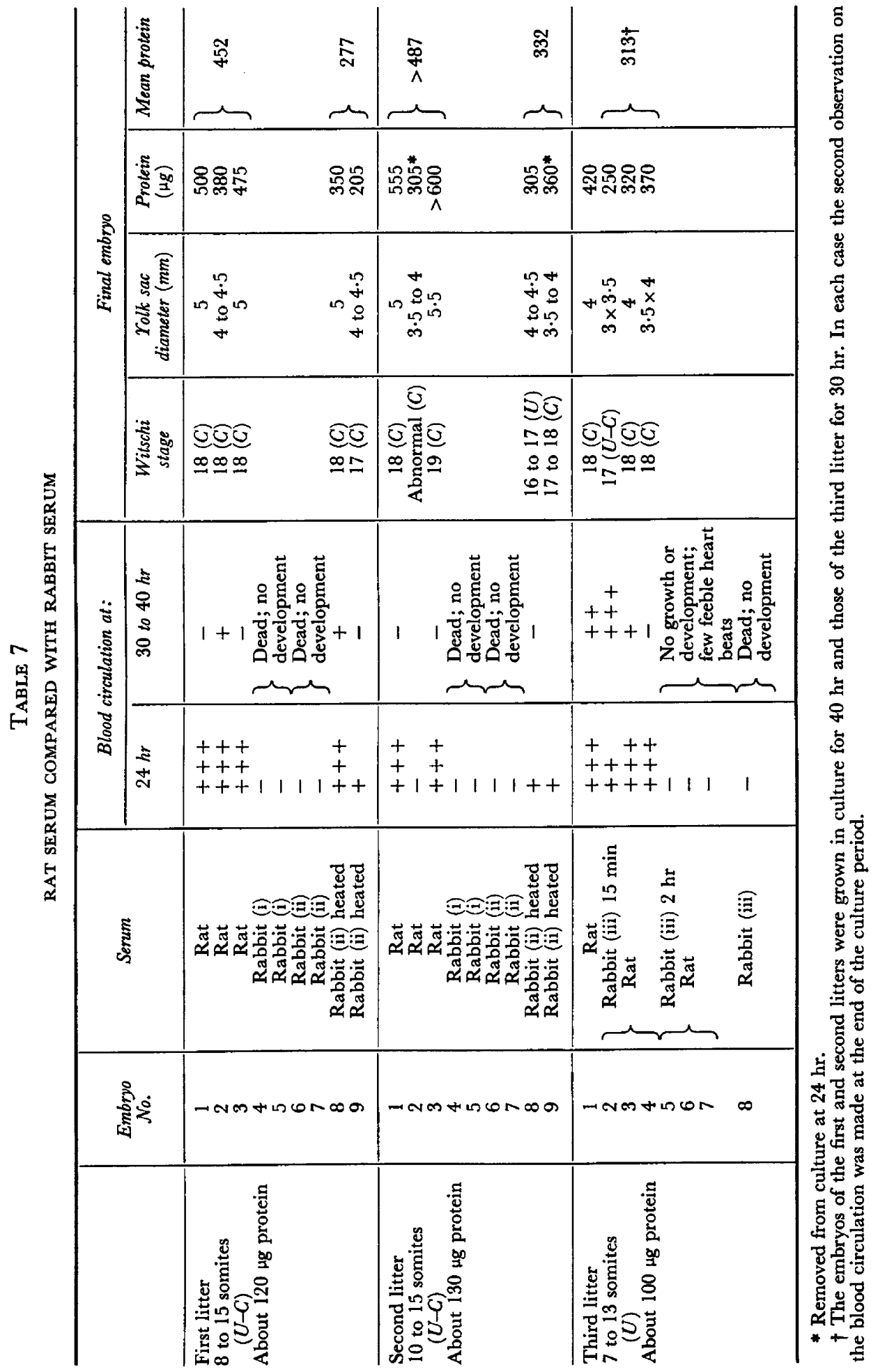




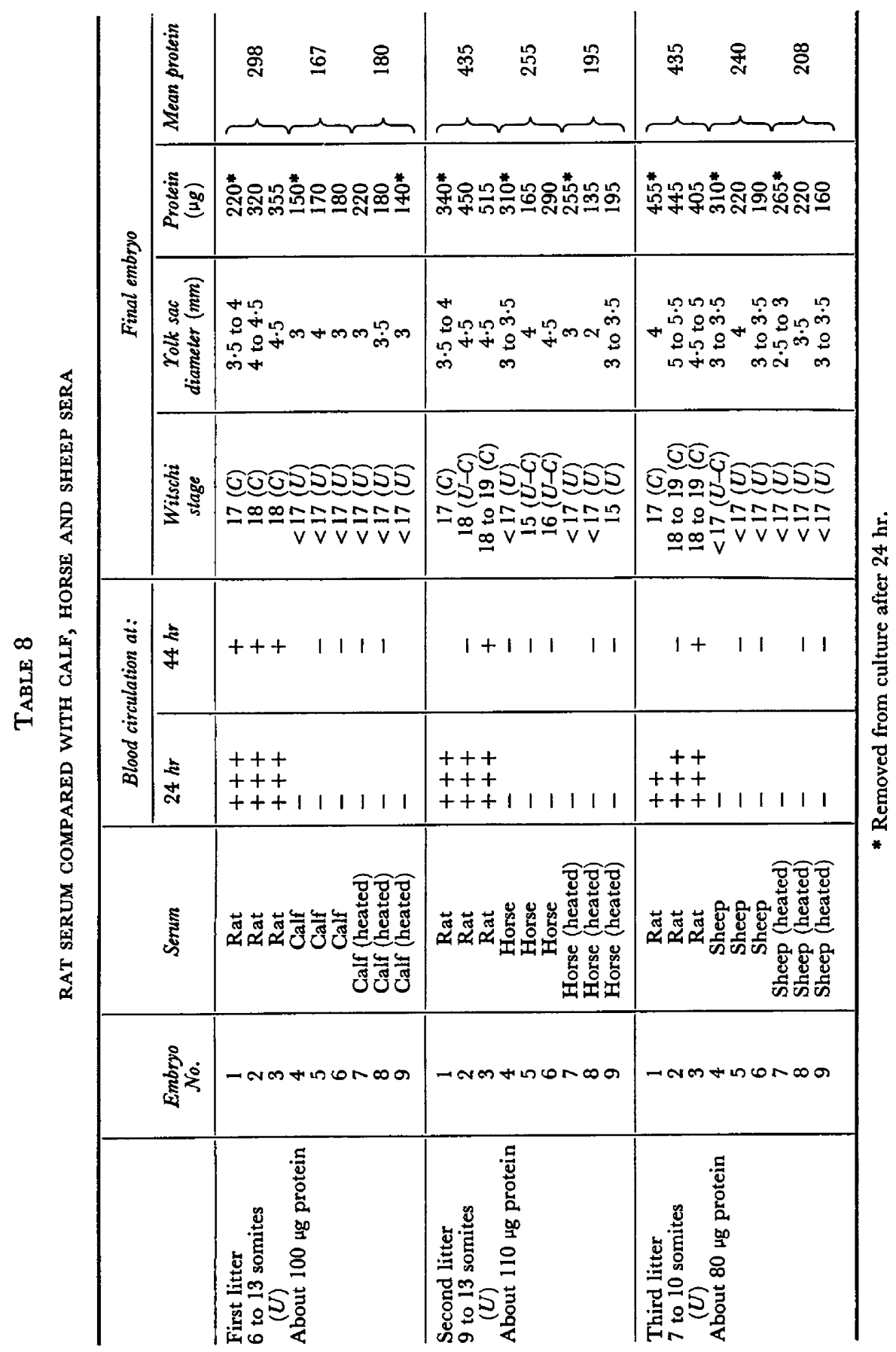




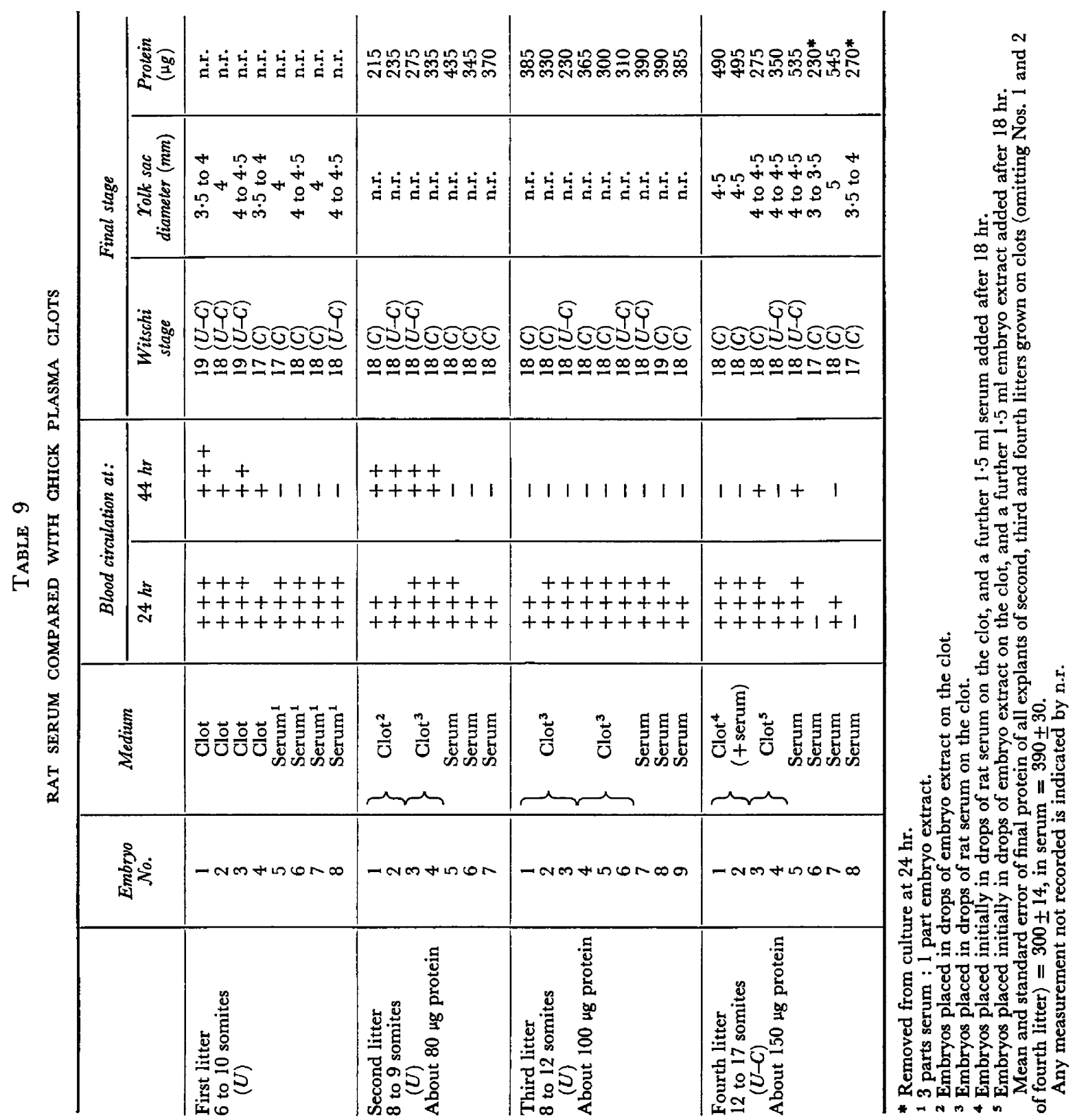


if any difference whether the serum is obtained from male or female rats, from pregnant or non-pregnant females, from the same individual as the embryos or from some other, from the same variety of rat as the embryos or from another. Heterologous sera, however, are unsatisfactory.

An earlier study of the development of rat embryos in homologous serum was made by Jolly \& Lieure (1938), but the results they reported are surprisingly poor. Few of their embryos appear to have developed beyond the 10 to 12 somite stage, and only $9 \%$ formed a functioning blood circulation. One reason for this may be that their embryos were cultured in air, whereas those in the present experiments were all in 60 to $70 \% \mathrm{O}_{2}$ and 3 to $4 \% \mathrm{CO}_{2}$. But probably more important was the age of the embryos at explantation. Jolly \& Lieure appear to have worked mainly with embryos explanted at primitive streak and head-process stages, whereas in these experiments the embryos have usually been explanted after they have developed the first somites. Embryos with a few somites develop very much better on clots than those only a few hours younger at presomite stages (New \& Stein, 1964), and the same seems to be true of development in serum. Not only do the somite embryos develop in culture to more advanced stages, but at the end of the culture period they resemble much more closely control embryos grown in vivo. It seems that some important change in the embryo's requirements occurs at the time that it is developing the first few somites; what this change is and why it occurs remain, at present, interesting but unsolved problems.

Heterologous sera have often been found to be harmful to tissues in culture unless previously heated at about 55 to $57^{\circ} \mathrm{C}$. The damage to the tissue appears to be due to an immunity reaction which requires the 'complement' present in the serum, and it is the complement that is destroyed by the heat treatment. Chang (1949) found that rabbit eggs were similarly affected; although most of the eggs developed normally in rabbit, horse, rat or guinea-pig serum, they were killed within $10 \mathrm{~min}$ by immersion in human, sheep, cattle, goat or fowl serum; these lethal sera became harmless, however, if heated at $55^{\circ} \mathrm{C}$ for $30 \mathrm{~min}$. The work described here has shown that rabbit serum is rapidly lethal to rat embryos but becomes less harmful if pre-heated. Some samples of fowl serum gave similar results, but others (possibly affected by longer storage) supported fairly good development of rat embryos; fowl plasma clots also provide a fairly reliable culture medium for these embryos. Some commercially prepared samples of calf, horse and sheep serum, although not as rapidly lethal to rat embryos as fresh rabbit serum, proved to be very inferior to rat serum as culture medium.

The most advanced stage attained by the embryos in culture is about 30 somites, Witschi Stage 19; most of the embryos cease development a little before this, at about Stage 18. The experiments with different amounts of serum suggest that death at this stage is not the result of the medium having become exhausted of some required nutrient. Provided a minimum of $0.5 \mathrm{ml}$ serum is initially present in the culture, no advantage is gained by increasing this quantity or by transferring the embryos to fresh serum after $24 \mathrm{hr}$. It is possible, however, that the embryo is unable to obtain nutrients and oxygen fast enough from the serum. At this stage the embryos in vivo are growing 
extremely rapidly -increasing in weight about five-fold per day-and the allantoic placenta is becoming an important organ of exchange between mother and foetus. In culture, not only does the allantoic placenta fail to develop, but, as the embryo approaches the 25 to 30 somite stage, the heart beat slows down and the yolk sac circulation fails. Experiments are being continued on the nutrient requirements of the embryos, and on the possibility of prolonging development in vitro by the use of circulating medium and hyperbaric oxygen.

\section{ACKNOWLEDGMENTS}

I am grateful to Professor Dame Honor B. Fell for encouragement and advice, and to Mrs J. R. Wallage for technical assistance. I would also like to thank Mr M. M. Turbow for help with some of the preliminary experiments.

\section{REFERENCES}

Chang, M. C. (1949) Effects of heterologous sera on fertilized rabbit ova. F. gen. Physiol. 32, 291.

Fell, H. B. \& Robison, R. (1929) The growth, development and phosphatase activity of embryonic avian femora and limb buds cultivated in vitro. Biochem. 7. 23, 767.

Jolly, J. \& LieUre, C. (1938) Recherches sur la culture des oeufs des mammifères. Archs Anat. microsc. 34, 307.

Lowry, O. H., Rosebrough, N. J., Farr, A. L. \& Randall, R. J. (1951) Protein measurement with the folin phenol reagent. F. biol. Chem. 193, 265.

New, D. A. T. \& STEIN, K. F. (1964) Cultivation of post-implantation mouse and rat embryos on plasma clots. F. Embryol. exp. Morph. 12, 101.

WrrschI, E. (1962) Development: Rat. In: Growth. VII. Prenatal Vertebrate Development. Eds. Altman and Dittmer. Biological Handbooks of the Federation of American Societies for Experimental Biology, Washington. 